\title{
PRODUCTION, CARCASS, AND MEAT QUALITY \\ CHARACTERISTICS OF COMMERCIAL CROSSBRED \\ GILTS AND BARROWS FED TWO DIFFERENT DIETS
}

\author{
By \\ KASSINDRA JO WINN \\ Bachelor of Science in Animal Science \\ Oklahoma State University \\ Stillwater, Oklahoma \\ 2012
}

Submitted to the Faculty of the

Graduate College of the

Oklahoma State University

in partial fulfillment of

the requirements for

the Degree of

MASTER OF SCIENCE

May, 2014 


\section{PRODUCTION, CARCASS, AND MEAT QUALITY CHARACTERISTICS OF COMMERCIAL CROSSBRED GILTS AND BARROWS FED TWO DIFFERENT DIETS}

Thesis Approved:

\begin{tabular}{c} 
Dr. Gretchen Mafi \\
\hline Thesis Adviser \\
Dr. Deb VanOverbeke \\
Dr. Ranjith Ramanathan
\end{tabular}




\section{ACKNOWLEDGEMENTS}

First, I want to thank my advisor Dr. Gretchen Mafi for taking me on as a graduate student and presenting me with many opportunities along the way, such as coaching the 2013 Meat Judging Team. In addition, I want to thank Dr. Deb VanOverbeke and Dr. Ranjith Ramanathan for assisting me throughout my two years as a graduate student and being on my committee. To my fellow graduate students and undergraduate research assistants, thank you for experiencing this journey with me, you all are the best! Also, I want to give a big thanks to the employees at the OSU Swine Research and Education Center and the Food and Agricultural Products Center for selecting, feeding, transporting, and slaughtering the hogs utilized in my study. 
Name: Kassindra Jo Winn

Date of Degree: May 2014

Title of Study: PRODUCTION, CARCASS, AND MEAT QUALITY

CHARACTERISTICS OF COMMERCIAL CROSSBRED GILTS AND BARROWS FED TWO DIFFERENT DIETS

\section{Major Field: Animal Science}

Abstract: This study analyzed the characteristics of commercial crossbreds by gender and diet on carcass merit by evaluation of cutability and palatability attributes of fresh pork. Duroc $\times$ Landrace $\times$ Yorkshire (commercial crossbred) barrows and gilts $(n=67)$ were utilized, and fed one of two corn based diets, with one containing $14 \%$ wheat midds (diet 1) and the other combining 12\% soybean meal and $9 \mathrm{~g}$ per ton of Paylean ${ }^{\circledR}(\operatorname{diet} 2)$. Hogs were harvested at the Oklahoma State University Food Agriculture Processing Center. Prior to slaughter, ultrasonic measurements of loin eye area (LEA) and $10^{\text {th }}$ rib fat depth $(n=88)$ were collected, and days of age, live weight and ADG were recorded for each hog. Carcass characteristics including $\mathrm{pH}$, hot carcass weight (HCW), fat depth, LEA, and quality attributes were measured, and fat free lean (FFL), \% FFL, and U.S. Grade were calculated for each carcass. A trained sensory panel evaluated cooked chops for juiciness, tenderness, and pork flavor. Barrows were faster growing with a higher ADG $(P<0.05)$ and were numerically $1.51 \mathrm{~kg}$ heavier $(P>0.05)$. No differences were observed between diet 1 and 2 for live weight $(P=0.37)$ and ADG $(P=0.29)$. Numerically, gilts had larger LEA, lower dressing $\%$, and greater FFL $(P>0.05)$. Barrows had numerically heavier HCW and higher MS $(P>0.05)$, but were fatter opposite the first and last rib, last lumbar vertebra (LLV), and $10^{\text {th }} \mathrm{rib}$, and calculated lower \%FFL and higher U. S. Grade $(P<0.05)$. There were no differences $(P=0.28 ; P=$ 0.22 ) in HCW between gender and diet. Hogs fed diet 1 had numerically heavier HCW, less fat over LLV, larger LEA, and calculated higher FFL, \% FFL, and lower U. S. Grade $(P>0.05)$. Gender or diet had no impact on quality attributes or $1 \mathrm{hr}, 3 \mathrm{hr}$, and $24 \mathrm{hr} \mathrm{pH}$ values. There were gender $\times$ diet interactions $(P<0.05)$ for initial/sustained juiciness and tenderness and pork flavor. Data suggests carcass merit and production were maximized by diet and gender, without sacrificing quality attributes. 
TABLE OF CONTENTS

Chapter

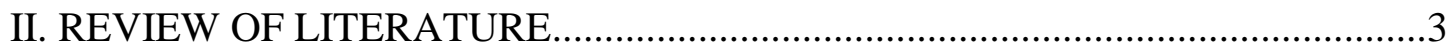

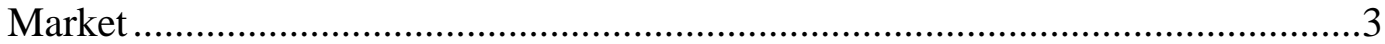

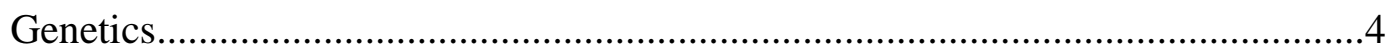

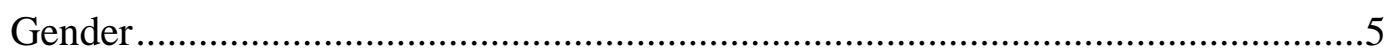

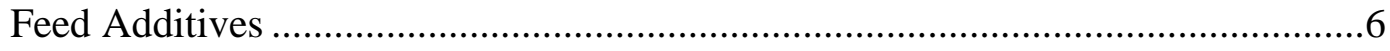

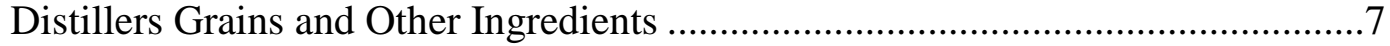

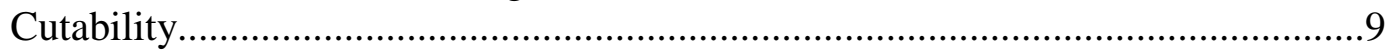

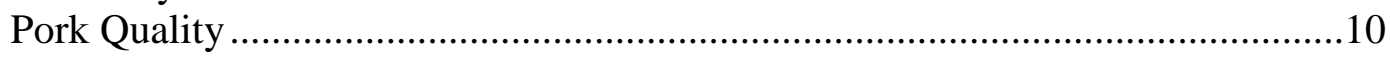

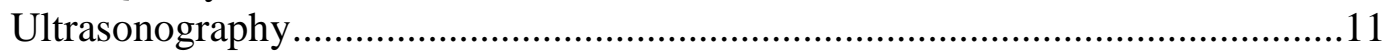

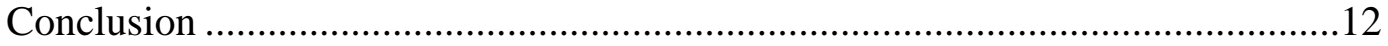

III. PRODUCTION, CARCASS, AND MEAT QUALITY CHARACTERISTICS OF COMMERCIAL CROSSBRED GILTS AND BARROWS FED TWO DIFFERENT DIETS

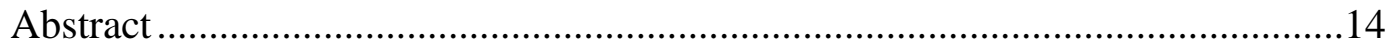

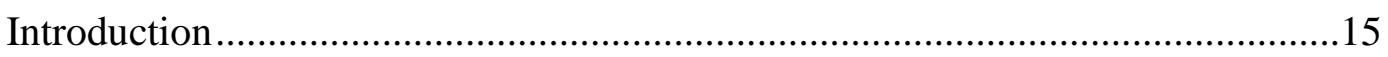

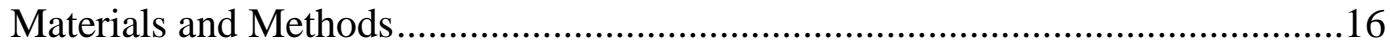

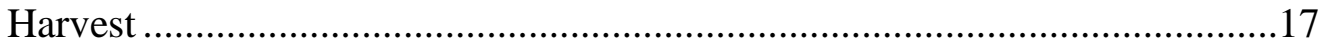

Carcass Characteristics ......................................................................... 18

Sensory Evaluation ....................................................................... 18

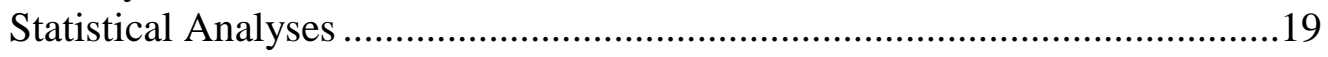

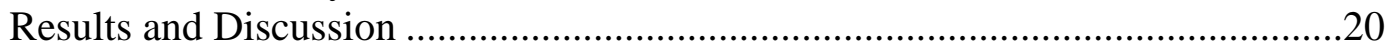

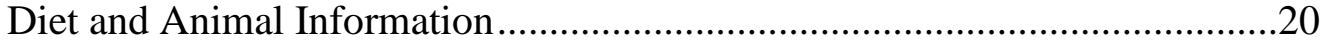

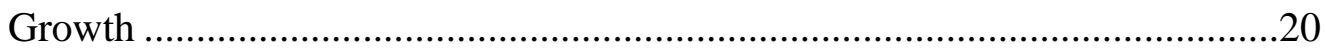

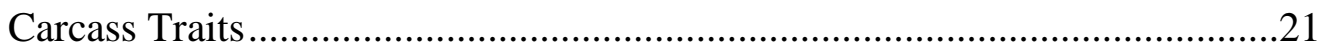

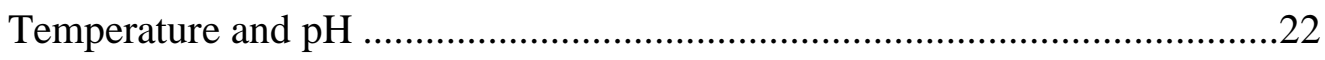

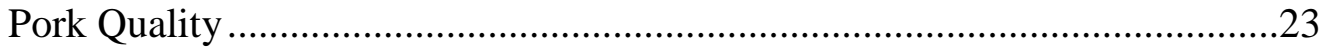

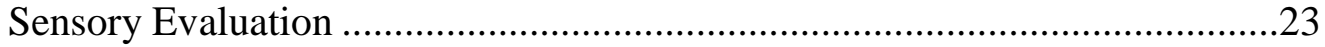

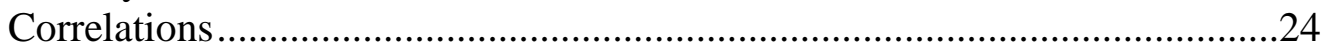




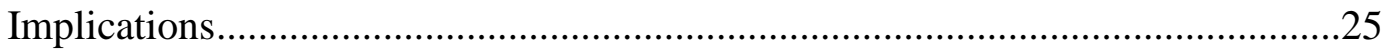

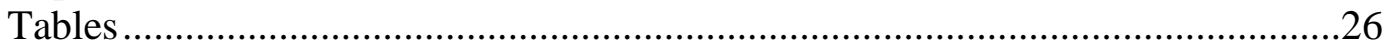

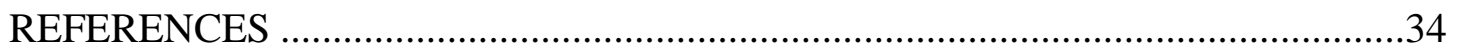




\section{LIST OF TABLES}

Table

Page

Diet composition of the two diets utilized in study with one including $14 \%$ wheat midds and the other combining $12 \%$ soybean meal and $9 \mathrm{~g}$ per ton of Paylean ${ }^{\circledR}$..... .26 Number of crossbred animals included in the study by gender and diet 27 Least squares mean for days of age, live weight, and ADG of crossbred gilts and barrows fed either diet 1 or diet 2 . .28 Least squares mean for carcass traits of crossbred gilts and barrows fed either diet 1 or $\operatorname{diet} 2$. 29 Least squares mean for $\mathrm{pH}$ and temperature values of the semimembranosus muscle of the ham and the longissimus dorsi muscle of the loin of crossbred gilts and barrows fed either diet 1 or diet 2 30

Least squares mean for subjective assessments of pork quality attributes of muscle color, texture, and firmness by evaluation of the cut surface of the loin chops provided by crossbred gilts and barrows fed either diet 1 or diet 2

Least squares mean for subjective assessments of pork quality attributes of juiciness, tenderness, and pork flavor of loin chops provided by crossbred gilts and barrows fed either diet 1 or diet 2 .

Correlations between actual and ultrasound measurements of $10^{\text {th }}$ rib fat depth and LEA 
for commercial crossbred and purebred Yorkshire gilts and barrows $(\mathrm{n}=88)$ 


\section{CHAPTER I}

\section{INTRODUCTION}

With the industrialization of the pork industry and increasing demand for leaner meat products by consumers over the past $25 \mathrm{y}$, pork producers have dramatically changed their production practices. Today, the pork industry consists of larger operations that sell contracted pork based on a "carcass merit" pricing system in which the price is calculated by evaluation of specific attributes of the individual animal and the carcass it yields (Pork Checkoff, 2012). Therefore, pork producers have implemented more economical and efficient feeding methods, breeding techniques, and management practices to enhance animal and carcass quality that generates an increasing steady income within their operations.

Pork is the most consumed meat in the world, making up $40 \%$ of the world's meat consumption (USDA, 2008). In December 2013, the U.S. slaughtered 9.7 million head, which is a $3 \%$ increase from December 2012 (USDA, 2014). Not only is the U.S. one of the largest pork producing countries in the world, it is also the number one pork exporter and has maintained that title since 2005 (Pork Checkoff, 2012). USDA's Foreign Agricultural Service (2013) predicts the U.S. will export approximately 2.4 million tons of pork in 2014. The supply of pork is determined by price of production input and 
technology costs, as well as the demand for pork and pork products by consumers (Pork Checkoff, 2012). Therefore, if prices are high in the swine industry, the supply of pork is not plentiful and production costs become overwhelming. With an abundant supply of hogs, pork prices decrease as do production costs.

For a pork producer to survive the increasing demand, it is important to understand the vital role carcass cutability and quality have in meat production in order to produce an end product that will meet the consumer's needs and expectations. Carcass cutability and quality are primarily impacted by sex, breed, age, genetics, and feed efficiency (Bereskin et al., 1978; Christian et al., 1980). Therefore, producers generate a consistent product through effective breeding decisions and improved feeding methods to increase the overall value of the animal.

The purpose of this study is to analyze the characteristics of gender and feed type that affect carcass merit by evaluation of cutability and palatability attributes. 


\section{CHAPTER II}

\section{REVIEW OF LITERATURE}

\section{Market}

Hogs are marketed based on lean value. A carcass merit pricing system was introduced to pork producers in the 1980 s, and now more than $75 \%$ of U.S. producers sell their hogs based on this marketing system (Schroeder et al., 2004). With the introduction of carcass merit systems, cash markets have declined and marketing contracts have been established. Pork producers and packers, such as Smithfield, Seaboard, and Cargill, have integrated production with processing to assure greater supply, quality control, and traceability advantages (Plain et al., 2001). Marketing contracts consist of a base price, provided by negotiating a cash market price and the implementation of discounts and premiums associated with carcass characteristics (Schroeder et al., 2004). The system allows producers to value the hog individually and not just by solely relying on live weight to maximize their profit potential. Therefore, percent muscle is vital when marketing hogs as it pays a premium in the end.

The U.S. Environmental Protection Agency (2013) suggests Americans have become more health conscious, thus demanding leaner meats that are lower in fat content. The demand for leaner hogs that currently drives the pork industry is known as part of the "niche market phenomenon" (Honeyman et al., 2006). Pork production began to 
concentrate more on the hog's ability to convert feed to protein more efficiently, creating a leaner type of hog (U.S. Environmental Protection Agency, 2013). Past research has proven there is a relationship between selective breeding and the ability to produce leaner hogs at an efficient rate (Armstrong et al., 2004). The marketing strategy begins with genetic control as producers select breeds of hogs that are leaner in type. Then the producers must determine the amount of time and money it takes for a group of hogs to reach their ideal slaughter weight (Hinson et al., 2012). According to Hinson et al. (2012), feed costs, carcass base price, available floor space, and packer payment schemes are all impacted by optimal slaughter weight. Therefore, once a producer can determine the number of days it takes to reach that ideal weight, they are able to develop a specific protocol to increase hog numbers and feeding techniques that will empty the barns at a consistent rate (Hinson et al., 2012).

\section{Genetics}

Genetics maintain a vital role in the production of pork. Different breeds offer certain characteristics that can affect performance and carcass composition. Producers select hogs based off of phenotypic characteristics and estimated heritabilities of previous offspring from that specific genetic line (Lo et al., 1992). Most hogs in the U.S. are produced through a crossbreeding system to exploit heterosis and breed complementarity (McLaren et al., 1987). According to Schneider et al. (1982), crossbreeding is a successful tool used in the U.S. to increase heterosis traits for performance and mothering ability. There are three crossbreeding systems being utilized in pork production: 3 breed rotational, terminal, and rotaterminal. The Global Swine Exchange (2012) of Iowa provides the advantages and disadvantages of each system. The 3 breed rotation 
maintains $86 \%$ heterosis in both offspring and sows; however, breed composition is manipulated with each generation. Terminal and rotaterminal maintain $100 \%$ heterosis in market hogs, which complements purebred strengths to full potential (Global Swine Exchange of Iowa, 2012). These systems allow breeders to cross the strengths of each breed to produce an ultimate product that represents both breed types effectively.

Since the 1980s, the Duroc breed has claimed the top spot in meat quality. When determining which breed of hog is the strongest in terms of pork quality, the National Pork Producers Council (2004) found the Duroc breed to surface to the top with excellent intramuscular fat, juiciness, and tenderness scores. When following a niche market, it has become essential to follow genetic lines, because producers want to increase value based on carcass traits. It is important for pork producers to select hogs which have proven to return leaner growth rates, greater carcass lean percentages, and higher gain to feed ratios into their potential offspring before the addition of supplements into the diet (Schnickel et al., 2003).

\section{Gender}

Due to hormonal changes within an animal's body, it is proven the animal's sex can affect performance and carcass composition in swine. Gilts tend to gain slower than barrows, but are more efficient eaters, generate higher yielding carcasses with less backfat, a larger loin eye area, and produce a greater percentage of leaner cuts (Plimpton, 1972). Barrows gain faster than gilts, but it is revealed that castration reduces carcass length and yields $3 \%$ less leaner cuts and $2 \%$ less edible portions compared to boars (Plimpton, 1972). Boars are more efficient than barrows and gilts and yield leaner carcasses. However, one-third of boars produce a sex odor that can be found in the aroma 
and flavor of the meat (Plimpton, 1972). Thus, gilts and barrows are fed to finish in swine operations, due to their efficient ability to convert feed to gain and provide leaner carcasses that do not have a distinct sex odor or taste.

\section{Feed Additives}

Ractopamine hydrochloride, also known as Paylean ${ }^{\circledR}$, is a $\beta$-adrenergic agonist feed additive utilized in finishing swine diets to increase average daily gain and carcass composition (Ross, 2011). Since December 1999, Paylean ${ }^{\circledR}$ has impacted the hog industry tremendously as it is the only Food and Drug Administration (FDA) approved phenethanolamine $\beta$-adrenergic agonist dietary supplement on the market for finishing swine (Bohrer et al., 2012). Paylean ${ }^{\circledR}$ is not an antibiotic, hormone, or steroid. It is described as a repartitioning agent that directs nutrients away from fat deposition and instead guides those nutrients towards lean muscle accretion (Premier Nutrition Technologies, 2006).

This feed additive introduced by Elanco Animal Health (Greenfield, IN) promises to produce more muscle and less fat when adding it to a feed ration containing at least $16 \%$ crude protein for the last 20 to 40 kilograms of gain approximately $35 \mathrm{~d}$ prior to slaughter, resulting in higher valued lean cuts of meat with no withdrawal period (Elanco, 2012). With the use of feed additives, there are different types of feeding strategies being utilized within an operation. The different types of feeding strategies include a step-up method which increases the amount of Paylean ${ }^{\circledR}$ fed over a specific amount of time. Others are simply fed for a longer period of time due to slower growth rates. Some are just being fed Paylean ${ }^{\circledR} 7 \mathrm{~d}$ prior to slaughter (Bohrer et al., 2012). Thus, the duration for this feed additive may vary for each pig, creating a different outcome when being 
analyzed (Hinson et al., 2012). According to Gerlemann et al. (2014), Paylean ${ }^{\circledR}$ improves average daily gain (ADG), feed-to-gain ratio, and carcass leanness by at least $2 \%$. With the addition of Paylean ${ }^{\circledR}$ to the diet, producers can manage: live weights, allocated space per pig, carcass composition, and input costs (Gerlemann et al., 2014).

It is suggested that an increase in muscle mass, would result in a decrease in pork quality. However, past research has proven that with the addition of Paylean®, there was no effect on pork juiciness and flavor (Carr et al., 2005). According to Carr et al. (2005), tenderness was affected linearly by sensory testing with the increase of ractopamine in the diet, but there were no differences in Warner Bratzler Shear (WBS) force values among dietary treatments. Even though studies have shown a decrease in pork tenderness, this negative effect can be diminished by lengthening the post-mortem aging time to at least $10 \mathrm{~d}$ (The Pig Site, 2013). Pork quality was not significantly affected by the utilization of this feed additive (Leick et al., 2010).

\section{Distillers Grains and other Ingredients}

According to Pork Checkoff (2012), more than 65\% of all production costs in the swine industry are found in feed supply. The conversion of feed to gain ratio can be represented by pounds of feed required per pound of live weight. On average, hogs are fed anywhere from 3.0 to $1.45 \mathrm{~kg}$ of feeds to gain $0.45 \mathrm{~kg}$ of live weight (Pork Checkoff, 2012).

Due to the utilization of corn in ethanol production, corn has increased in price causing livestock producers to find alternative ingredients besides corn and soybean meal that will lower feed costs, but not sacrifice growth performance (Salyer et al., 2012). One of these alternative ingredients is distillers dried grains with solubles (DDGS). Distillers 
dried grains are a byproduct produced during the fermentation and distillation processes of corn to generate ethanol (Thaler, 2002). According to Thaler (2002), one bushel of corn produces roughly $7.71 \mathrm{~kg}$ of DDGS. One thousand bushels of grain creates 8 - 9 tons of DDGS, with dry-mill distillers processing 50 - 250 thousand bushels of grain per day (Distillers Grains Technology Council, 2005). According to Sayler et al. (2012) and Pederson et al. (2007) DDGS contains approximately 3 times more crude protein, fat, and fiber compared to corn. Since there has been a great demand for ethanol in the U.S., DDGS is in abundance and is being used as an additional protein and energy source to feed finishing livestock. Dried distiller grains have been used in the swine industry for half a century (Stein et al., 2008). Experiments confirm that between 5\% and 30\% corn DDGS can be introduced into the grower-finisher diets without effecting hog growth performance (Stein et al., 2008).

In addition to DDGS, wheat midds are another common cereal by-product used in finishing swine diets (Salyer et al., 2012; Cromwell, 2000). According to Pork Check Off (2008), $45 \mathrm{~kg}$ of wheat midds will replace $39 \mathrm{~kg}$ of corn, $5 \mathrm{~kg}$ of high protein soybean meal, and $0.68 \mathrm{~kg}$ of monocalcium phosphate, replacing the lysine and phosphorus found in corn and soybean meal. Wheat midds contain more crude protein and fiber compared to corn (Sayler et al., 2012; NRC, 1998). However, wheat midds have been found to decrease metabolic energy concentration, which can cause gain and feeding efficiency to decrease when added to corn and soybean meal based diets (Salyer et al., 2012; Shaw et al., 2002). 


\section{Cutability}

To determine the value of pork carcasses, it is important to understand cutability and quality characteristics. Cutability is analyzed by a lean to fat ratio. At time of slaughter, each carcass is sorted into a class based on sex orientation and given a grade by an assessment of quality and yield characteristics (USDA, 2013). The USDA created standards for class and grades in 1931 and continually made revisions to the standards over time to incorporate the changes being made within the pork slaughter industry, with the last revision completed in 1985.

Pork carcasses can be sorted into five classes: boar, barrow, stag, sow, and gilt. However, USDA official standards (1985) only provide a grade for barrows, gilts, and sows. A grade is given by measuring fat thickness over the last rib and providing a muscle score (USDA, 1985). Pork carcasses are given a U.S. Grade ranging between No. 1, 2, 3, and 4; No. 1 representing leaner carcasses yielding $60.4 \%$ or higher and No. 4 with carcasses yielding less than 54.4\% (USDA, 1985).

Grades are determined by measuring the last rib back fat (LRBF) and degree of muscling, which is subjectively determined by thickness. A muscle score (MS) is given as a result of evaluated thickness: 1-thin, 2-average and 3-thick. This grading system utilizes the equation: (4 x LRBF) - MS to calculate a U.S. Grade (USDA, 1985). Pounds

of fat free lean $\left(\right.$ Pounds of fat free lean $=8.588-\left(21.896 \times 10^{\text {th }}\right.$ rib fat depth $)+(3.005 \times$ $\mathrm{LEA})+(0.465 \times \mathrm{HCW})$, percentage of fat free lean $(\% \mathrm{FFL}=($ pounds of $\mathrm{FFL} \div \mathrm{HCW} \times$ $100)$, and dressing percentage $(\mathrm{D} \%=\mathrm{HCW} \div \mathrm{LW} \times 100)$ are calculated to determine value of hogs. 


\section{Pork Quality}

According to USDA standards for pork carcasses (1985), grades for carcasses are based on quality and the potential yield of the four lean cuts (ham, loin, shoulder, and boston butt). Carcasses are either deemed acceptable or unacceptable in quality. Pork carcasses are not usually ribbed and are evaluated by indirect indicators. These indicators include a variation of measurements on different locations of the carcass, with most measurements representing fat content and an indirect evaluation of lean meat (Kosovac et al., 2009). Other indicators evaluated are color of the lean, firmness of fat and lean, amount of feathering between the ribs, and belly thickness (USDA, 1985).

The $\mathrm{pH}$ value of meat is important in meat production as it can aid in the determination of shelf life of the product and quality acceptability of the product. The conversion of muscle to meat during rigor mortis affects the $\mathrm{pH}$ values in meat. In swine production, the normal $\mathrm{pH}$ of hogs prior to slaughter is 7.1. However, after slaughter, pork possess a $\mathrm{pH}$ value of 5.4 to 5.8 . The $\mathrm{pH}$ value can be influenced by breed and treatment of the animal before slaughter (Eutech Instruments, 1997).

Two major problems exist in the swine industry due to rapid $\mathrm{pH}$ value change. These two problems are 1) pale, soft, and exudative (PSE) and 2) dark, firm, and dry (DFD), both occur $10 \%$ to $16 \%$ in market hogs within the U.S. (Freise, 2005). Pale, soft and exudative occurs from rapid postmortem metabolism of glycogen to lactic acid within the first hour of rigor mortis resulting in $\mathrm{pH}$ value of 5.2 (Freise, 2005). Bowker et al. (2000) found PSE meat is characterized by pale colored lean with a soft texture and has a low water-binding capacity. Pale, soft, and exudative deems pork product unacceptable in quality. Dark, firm, and dry results from the depletion of glycogen within 
the muscle prior to slaughter, which reduces the production of lactic acid after slaughter, thus the $\mathrm{pH}$ value and water binding capacity remains high (Kauffman et al., 1978).

Pale, soft, and exudative can be increased in carcasses of hogs that suffer from Porcine Stress Syndrome (PSS) or normal hogs that experience pre-slaughter stress during handling. The 1991 National Pork Producers Council reported that the lean quality of hams from 10,753 carcasses slaughtered from 14 major packing plants throughout the U.S. produced $16 \%$ carcasses with PSE and 10\% with DFD. With improvement of genetics and technology, producers are able to breed hogs without the influence of Porcine Stress Syndrome. In addition, if proper handling methods are used, hogs should experience no pre-slaughter stress, and incidences of PSE and DFD can be reduced.

\section{Ultrasonography}

With the improvements in technology, pork producers have implemented different types of methods into their program to assure leaner hogs are being produced to meet the consumers' demand. One of these methods includes the utilization of ultrasonography for lean prediction purposes and breeding selection. According to Boland et al. (1995), the success to any carcass merit system is the ability to predict carcass composition accurately and objectively. Thus, a new technology which has surfaced is real-time ultrasound. The use of ultrasonography in animal science began in 1956, as staff members at Colorado A \& M College (Colorado State University) utilized a human medical ultrasonic unit to measure back fat thickness on beef cattle (Stouffer, 2004). Stouffer (2004), admitted that to accurately predict body composition, it was important to measure muscle mass (ribeye or loin eye area) in addition to back fat thickness. 
During the early 1960s, predicted carcass measurements by the use of ultrasound were provided to judges at the International Livestock Exposition in Chicago, IL, to aid in the ranking of live animals (Stouffer, 2004). It was said there was a great need for an objective evaluation, as it was difficult to visually assess what was under the hide of an animal (Stouffer, 2004). Real-time ultrasound allows the producer to estimate backfat depth and muscle dimension in an economically feasible method to predict carcass yield in live swine (Stouffer, 2004). As the development of ultrasound equipment progressed, research revealed the transducer took more accurate measurement when mounted to a carriage that moved along a fixed, curved guide with a sharper curve utilized in pigs (Stouffer, 2004). The estimation of backfat depth and muscle dimension aids producers in selecting breeding stock to improve carcass quality in future generations of pigs (Kuhlers et al., 1998; Lo et al., 1992). Not only does ultrasonography aid in the breeding selection, but it has also been used in pork carcass evaluation post-slaughter. In 1995, the carcass value technology system (CVT) was established in many meat-packing plants in the United States to evaluate the carcass characteristics necessary to predict percent lean and provide payment to the producer quicker (Stouffer, 2004).

\section{Conclusion}

With the demand for leaner products, effective breeding decisions and improved feeding methods are necessary in pork production to increase overall value of the animal and generate a consistent product. The implementation of crossbreeding and more efficient feeding strategies allow pork producers to economically increase production numbers without sacrificing their bottom line. They are able to face the challenge of a niche market and produce leaner hogs that will satisfy the consumer. Schinckel et al. 
(2003) states the objective of pork producers is to maximize daily returns that are above feed costs. Therefore, it is important for research to be conducted on the effects of gender and diet in hog production to produce a high quality product that aids in decreasing production costs. 
CHAPTER III

\title{
PRODUCTION, CARCASS, AND MEAT QUALITY CHARACTERISTICS OF COMMERCIAL CROSSBRED GILTS AND BARROWS FED TWO DIFFERENT DIETS
}

\begin{abstract}
This study analyzed the characteristics of commercial crossbreds by gender and diet on carcass merit by evaluation of cutability and palatability attributes of fresh pork. Duroc $\times$ Landrace $\times$ Yorkshire (commercial crossbred) barrows and gilts $(\mathrm{n}=$ 67) were utilized, and fed one of two corn based diets, with one containing $14 \%$ wheat midds (diet 1) and the other combining $12 \%$ soybean meal and $9 \mathrm{~g}$ per ton of Paylean ${ }^{\circledR}$ (diet 2). Hogs were harvested at the Oklahoma State University Food Agriculture Processing Center. Prior to slaughter, ultrasonic measurements of loin eye area (LEA) and $10^{\text {th }}$ rib fat depth $(n=88)$ were collected, and days of age, live weight and ADG were recorded for each hog. Carcass characteristics including $\mathrm{pH}$, hot carcass weight (HCW), fat depth, LEA, and quality attributes were measured, and fat free lean (FFL), \% FFL, and U.S. Grade were calculated for each carcass. A trained sensory panel evaluated the cooked chops for juiciness, tenderness, and pork flavor. Barrows were faster growing with a higher ADG $(P<0.05)$ and were numerically $1.51 \mathrm{~kg}$ heavier $(P>0.05)$. No differences were observed between diet 1 and 2 for live weight $(P=0.37)$ and ADG $(P=$
\end{abstract}


0.29). Numerically, gilts had larger LEA, lower dressing $\%$, and greater FFL $(P>0.05)$.

Barrows had numerically heavier HCW and higher MS $(P>0.05)$, but were fatter

opposite the first and last rib, last lumbar vertebra (LLV), and $10^{\text {th }}$ rib, and

calculatedlower \%FFL and higher U. S. Grade $(P<0.05)$. There were no differences $(P=$ $0.28 ; P=0.22)$ in HCW between gender and diet. Hogs fed diet 1 had numerically heavier HCW, less fat over LLV, larger LEA, and calculated higher FFL, \% FFL, and lower U. S. Grade $(P>0.05)$. Gender or diet had no impact on quality attributes or $1 \mathrm{hr}, 3$ hr, and $24 \mathrm{hr} \mathrm{pH}$ values. There were gender $\times$ diet interactions $(P<0.05)$ for initial/sustained juiciness and tenderness and pork flavor. Data suggests carcass merit and production were maximized by diet and gender, without sacrificing quality attributes.

\section{INTRODUCTION}

With the industrialization of the pork industry and increasing demand for leaner meat products by consumers over the past $25 \mathrm{y}$, pork producers have dramatically changed their production practices. Today, the pork industry consists of larger operations that sell contracted pork based on a "carcass merit" pricing system in which the price is calculated by evaluation of specific attributes of the individual animal and the carcass it yields (Pork Checkoff, 2012). Therefore, pork producers have implemented more economical and efficient feeding methods, breeding techniques, and management practices to enhance animal and carcass quality that generates an increasing steady income within their operations.

Pork is the most consumed meat in the world, making up $40 \%$ of the world's meat consumption (USDA, 2008). In December 2013, the U.S. slaughtered 9.7 million head, 
which is a 3\% increase from December 2012 (USDA, 2014). Not only is the U.S. one of the largest pork producing countries in the world, it is also the number one pork exporter and has maintained that title since 2005 (Pork Checkoff, 2012). USDA's Foreign Agricultural Service (2013) predicts the U.S. will export approximately 2.4 million tons of pork in 2014. The supply of pork is determined by price of production input andtechnology costs, as well as the demand for pork and pork products by consumers (Pork Checkoff, 2012). Therefore, if prices are high in the swine industry, the supply of pork is not plentiful and production costs become overwhelming. With an abundant supply of hogs, pork prices decrease as do production costs.

For a pork producer to survive the increasing demand, it is important to understand the vital role carcass cutability and quality have in meat production in order to produce an end product that will meet the consumer's needs and expectations. Carcass cutability and quality are primarily impacted by sex, breed, age, genetics, and feed efficiency (Bereskin et al., 1978; Christian et al., 1980). Therefore, producers generate a consistent product through effective breeding decisions and improved feeding methods to increase the overall value of the animal.

The purpose of this study was to analyze the characteristics of gender and feed type that affect carcass merit by evaluation of cutability and palatability attributes

\section{MATERIALS AND METHODS}

Duroc $\times$ Landrace $\times$ Yorkshire (commercial crossbred) barrows and gilts $(n=67)$ were utilized in this study. Personnel from the Oklahoma State University Swine Research and Education Center selected, fed, and transported hogs prior to harvesting. 
Utilizing distillers grains, hogs were fed one of two corn based diets, with one containing $14 \%$ wheat mids (diet 1) and the other combining $12 \%$ soybean meal and $9 \mathrm{~g}$ per ton of Paylean ${ }^{\circledR}$ (ractopamine hydrochloride; diet 2). Age, feed rations, feed additives, sex, and genetics were provided by the OSU Swine Research and Education Center and presented in Table 1 and 2.

\section{Harvest}

Every Thursday between March 21, and May 16, 2013, hogs were weighed and transported to the Robert M. Kerr Food and Agricultural Products Center (FAPC) located on the Oklahoma State University campus to be slaughtered ( $\mathrm{n}=10 /$ day). Before rendered unconscious, loin eye area (LEA) and $10^{\text {th }}$ rib fat depth measurements $(n=88)$ were collected by a real-time ultrasound console (model SSD-500V, Hitachi Aloka Medical Ltd., Wallingford, CT) with a 172 mm linear transducer (model UST-5044-3.5, Hitachi Aloka Medical Ltd., Wallingford, CT). Loin eye area (LEA) and $10^{\text {th }}$ rib fat depth were measured on screen with a plastic USDA grid and steel probe. Measurements on screen were converted to actual size by equation $\left(\mathrm{LEA}=\right.$ recorded dots $\div 2 \times 2.63,10^{\text {th }}=$ recorded 10ths $\times 2.00$ ). Following completed harvest, $1 \mathrm{hr}, 3 \mathrm{hr}$, and $24 \mathrm{hr} \mathrm{pH}$ and temperature readings were recorded in the semimembranosus muscle of the ham and the longissimus dorsi muscle between the $10^{\text {th }}$ and $11^{\text {th }}$ ribs on both the left and right side of the carcass. Data were recorded by utilizing a hand-held pH meter (model IQ150, IQ Scientific Instruments, Inc., San Diego, CA) with a stainless steel probe attachment (part No. PH57-SS, IQ Scientific Instruments, Inc.) and a hand-held thermometer (model 34040-NSF, Cooper-Atkins Corp., Middlefield, CT). 


\section{Carcass Characteristics}

Hot carcass weight $(\mathrm{HCW})$, muscle score $(\mathrm{MS})$, dressing percentage $(\mathrm{HCW} \div \mathrm{LW}$ $\times 100)$, and first rib fat depth (FR), last rib fat depth (LR), and last lumbar vertebrae fat depth (LLV) were collected on both the left and right sides of the carcass. Six days postharvest, one $2.54 \mathrm{~cm}$ loin chop at the $10^{\text {th }}$ rib was collected from each carcass. Actual loin eye area (LEA) was determined by measuring the cross-sectional surface of the longissimuss dorsi with a USDA plastic grid. Tenth rib fat depth was measured $3 / 4$ opposite the loin eye with a USDA steel probe. Using the guidelines of the National Pork Producers Council (2000), a subjective assessment of color $(1=$ pale pinkish gray to white, $2=$ grayish pink, $3=$ reddish pink, $4=$ dark reddish pink $5=$ purplish red, $6=$ dark purplish red), texture ( $8=$ extremely fine textured, $1=$ extremely coarse $)$, and firmness $(1$ $=$ soft- cut surfaces distort easily and are visibly soft, $2=$ firm-cut surfaces tend to hold their shape, 3 = very firm-cut surfaces tend to be very smooth with no distortion of shape) were determined by evaluating the freshly cut surface of the loin chop. Pounds of fat free lean $\left(\right.$ Pounds of fat free lean $=8.588-\left(21.896 \times 10^{\text {th }}\right.$ rib fat depth $)+(3.005 \times$ $\mathrm{LEA})+(0.465 \times \mathrm{HCW})$, percentage of fat free lean $(\% \mathrm{FFL}=($ pounds of $\mathrm{FFL} \div \mathrm{HCW} \times$ 100), dressing percentage $(\mathrm{D} \%=\mathrm{HCW} \div \mathrm{LW} \times 100)$, and U.S. Grade $(4 \times \mathrm{LR}-1 \times \mathrm{MS})$ were calculated for each carcass. Actual loin eye area (LEA) and $10^{\text {th }}$ rib fat depth were compared to ultrasound results.

\section{Sensory Evaluation}

After measuring actual $10^{\text {th }}$ rib fat depth, LEA, and determining quality scores, a raw weight was collected from each chop, then chops were placed on an impingement oven (XLT Ovens, Model 3240TS2, BOFI, Wichita, KS) and cooked to an internal 
temperature of $70^{\circ} \mathrm{C}$ following the guidelines provided by the USDA (2011). After cooking, the chops were reweighed to obtain a cooked weight so cook loss could be calculated, and samples were cut into $1 \mathrm{~cm} \times 1 \mathrm{~cm} \times 2.54 \mathrm{~cm}$ pieces. Two pieces were placed into a plastic sample cup with a lid, and the cups were put into individual warmers with hot packs to sustain heat throughout the sensory session.

Trained sensory panelists were selected from Oklahoma State University personnel to determine the acceptability of pork. Up to five people served on each panel. Panelists were placed in a temperature and light controlled room in individual booths and were supplied with room temperature distilled, deionized water and unsalted crackers to cleanse their palates between samples. Samples were served and tasted under red light to avoid visual bias. Panelists evaluated chops for initial and sustained juiciness $(8=$ extremely juicy, $1=$ extremely dry $)$, initial and sustained tenderness $(8=$ extremely tender, $1=$ extremely tough $)$, and pork flavor $(8=$ extremely intense, $1=$ extremely bland). If an off flavor was detected, panelists commented in space provided on sensory ballot.

\section{Statistical Analysis}

Least squares means (LSmeans) and standard errors (SE) were calculated using the MIXED Procedure of SAS (SAS Inst. Inc., Cary, NC) with the individual hog as the experimental unit. The experiment was analyzed as a $2 \times 2$ factorial with gender (barrows and gilts), diets (DDGS or DDGS + 9g/ton Paylean $\left.{ }^{\circledR}\right)$ and their interaction as the fixed effects and harvest date as a random effect. For sensory attributes, harvest date and panelist were random effects in the model. When factors or their interactions were significant $(P<0.05)$, means were separated using pairwise t-test. Correlations between 
actual and ultrasound measurements of $10^{\text {th }}$ rib fat depth and LEA were calculated using Proc Corr procedures of SAS (version 9.2; SAS Inst. Inc.,).

\section{RESULTS AND DISCUSSION}

\section{Diet and Animal Information}

Table 1 contains information about the composition of diets utilized in this study. Animal information by gender and diet are included in Table 2. Hogs for the current study were selected, fed, weighed, and transported by Oklahoma State University Swine Research and Education Center personnel.

\section{Growth}

Results for growth traits such as days of age, live weight, and ADG are shown in Table 3. At harvest, crossbred gilts were $9 \mathrm{~d}$ older compared to barrows $(P<0.05)$. However, barrows were faster growing with a higher ADG $(0.71 \mathrm{~kg} / \mathrm{d} ; P<0.05)$ and were numerically $1.51 \mathrm{~kg}$ heavier than gilts $(P>0.05)$. There were no differences between diet 1 and diet 2 for live weight, ADG, and days of age $(P=0.37, P=0.29$, and $P=0.18)$, but hogs fed diet 1 were $6 \mathrm{~d}$ older and numerically had $(P>0.05)$ a heavier live weight $(122.45 \mathrm{~kg})$ in relation to hogs fed diet $2(120.64 \mathrm{~kg})$. However, hogs fed diet 1 had numerically $(P>0.05)$ lower ADG, which tends to support previous research from Salyer et al. (2012) who reported a decrease of ADG in pigs fed a diet containing a higher percentage of wheat midds. Even though hogs fed diet 2 had a slightly numerically higher ADG of $0.01 \mathrm{~kg} / \mathrm{d}$, they were slower growing and weighed less than hogs fed diet $1(P>$ 0.05). Overall, barrows were faster growing, taking fewer days on feed to reach ultimate

market weight. These results agree with past research, which reports barrows have greater 
feed intake and growth rate compared to gilts (Hamilton et al., 2003; Hyun et al., 2005; Brana et al., 2013). Average daily gain results from hogs fed diet 2 numerically agree with Carr et al. (2005), Apple et al. (2007), and Brana et al. (2013) who reports that with supplementation of Paylean ${ }^{\circledR}$ into the diet increased ADG.

\section{Carcass Traits}

There were no differences $(P=0.28$ and $P=0.22)$ in HCW between diet 1 and diet 2 or gilts and barrows, but numerically barrows and hogs fed diet 1 had a heavier HCW ( $P>0.05$; Table 4). Hogs fed diet 1, numerically had $1.83 \mathrm{~kg}$ heavier HCW, measured with $0.16 \mathrm{~cm}$ less fat opposite the last lumbar vertebra, a $1.60 \mathrm{~cm}^{2}$ larger LEA, and calculated with a higher FFL, \% FFL, and a lower U.S. Grade, compared to hogs fed diet $2(P>0.05$; Table 4$)$. In contrast, hogs fed diet 2 numerically measured with less fat opposite the FR, LR, and had less $10^{\text {th }}$ rib fat depth in relation to hogs fed diet $1(P>$ 0.05). Past research does not agree with the results of current study for hogs fed diet 1 , because Salyer et al. (2012) found that with an increase in wheat midds HCW, carcass yield, LEA, and fat depth decreased. Results from hogs fed diet 2 numerically support previous studies that indicate with supplementation of Paylean ${ }^{\circledR}$ into the diet resulted in a decrease of fat depth (Carr et al., 2005; Apple et al., 2007; Stoller et al., 2003).

Numerically, gilts had a larger LEA, a lower Dressing \%, and greater FFL in relation to barrows $(P>0.05)$. Compared to gilts, barrows numerically had a heavier HCW and a higher MS $(P>0.05)$, but measured with $0.44 \mathrm{~cm}$ more fat opposite the FR, $0.33 \mathrm{~cm}$ more fat opposite the LR, $0.40 \mathrm{~cm}$ more fat opposite the LLV, and had $0.34 \mathrm{~cm}$ more $10^{\text {th }}$ rib fat depth $(P<0.05)$. With an increase in fat depth, barrows numerically had a lower FFL $(P>0.05)$ and a significantly lower \%FFL and a higher U. S. Grade than 
gilts $(P<0.05)$. Results of fat depth support previous research as barrows are known to deposit more fat compared to gilts (Latorre et al., 2004). Undeniably, gilts produced leaner carcasses that measured with numerically $(P>0.05)$ less fat opposite the FR, LR, LLV, and less $10^{\text {th }}$ rib fat depth and had a higher \% FFL and a lower U. S. Grade than barrows $(P<0.05)$. These results concur with Latorrre et al. (2004) and Ellis et al. (1996) that report barrows produced heavier and fatter carcasses, and proportion of lean cuts were lower for barrows than gilts.

\section{Temperature and $\mathrm{pH}$}

There were no differences $(P>0.05)$ observed between gilts and barrows or hogs fed either diet 1 or diet 2 in $\mathrm{pH}$ value of the semimembranosus muscle of the ham or the longissimus dorsi muscle of the loin at $1 \mathrm{hr}, 3 \mathrm{hr}$, or $24 \mathrm{hr}$ (Table 5). At $24 \mathrm{hr}$, values for $\mathrm{pH}$ ranged between 5.4 and 5.7, which are considered normal and did not reveal any rapid declination. These results support previous studies which show $\mathrm{pH}$ values are not affected by supplementation of Paylean ${ }^{\circledR}$ into the diet. Thus, addition of wheat midds or supplementation of Paylean ${ }^{\circledR}$ did not increase the percentage of PSE or DFD in the current study. Also, these values support previous studies that found gender had no impact on muscle pH (Cisneros et al., 1996; Leach et al., 1996). Gilts and hogs fed diet 2 numerically had a higher $\mathrm{pH}$ value in the ham and loin at $1 \mathrm{hr}$ compared to barrows and hogs fed diet $1(P>0.05)$.

Hogs fed diet 1 had a significantly higher temperature in the semimembranosus muscle of the ham and the longissimus dorsi muscle of the loin at $3 \mathrm{hr}$ and a higher temperature in the loin at $1 \mathrm{hr}$ than hogs fed diet $2(P<0.05$; Table 5). Compared to gilts, barrows recorded a higher temperature in the loin at $3 \mathrm{hr}$ and $24 \mathrm{hr}(P<0.05)$. Overall, 
hogs fed diet 1 recorded higher temperatures at $1 \mathrm{hr}, 3 \mathrm{hr}$, and 24 in both the ham and loin in contrast with hogs fed diet 2.

\section{Pork Quality}

A subjective assessment of pork quality measurements for color, texture and firmness are presented in Table 6. There were no differences $(P>0.05)$ observed between gilts and barrows or hogs fed diet 1 or diet 2 in color, texture, firmness or cook loss $\%$. However, hogs fed diet 2 numerically presented more marbling in the cut surface of the longissimus dorsi muscle and were numerically firmer compared to hogs fed diet 1 $(P>0.05)$. Hogs fed diet 1 or diet 2 had no differences in muscle color $(P=0.80)$ or texture $(P=0.53)$. Numerically, barrows had a more desirable texture in the longissimus dorsi muscle compared to gilts $(P>0.05)$. Gilts numerically were firmer and had a more desirable reddish pink lean color on the cut surface of the loin eye than barrows $(P>$ 0.05). In relation to gilts and hogs fed diet 1 , cook loss $\%$ was numerically lower in barrows and hogs fed diet $2(P>0.05)$. According to Latorre et al. (2004), cooking losses were lower in loin chops from barrows than gilts. However, other studies have exhibited no differences in cooking loss percentages between genders (Cisneros et al., 1996; Ellis et al., 1996). These results follow the trends of past research, which indicates supplementation of Paylean® into the diet produced no differences in quality traits and will not affect purchasing decisions by consumers (Stites et al., 1991; Stoller et al., 2003; Apple et al., 2007).

\section{Sensory Evaluation}

There were gender $\times$ diet interactions $(P<0.05)$ for initial and sustained juiciness, tenderness, and pork flavor (Table 7). Panelists detected a greater initial and sustained 
juiciness in loin chops from gilts fed diet 1 and barrows fed diet 2 in relation to gilts fed diet 2 and barrows fed diet $1(P<0.05)$. Gilts fed diet 1 had greater $(P<0.05)$ initial tenderness compared to other treatment groups. Loin chops from gilts fed diet 1 and barrows fed diet 2 had greater sustained tenderness than gilts fed diet 2 and barrows fed diet $1(P<0.05)$. Gilts fed either diet 1 or diet 2 along with barrows fed diet 2 , had a more desirable pork flavor compared to barrows fed diet $1(P<0.05)$. There were no differences in initial tenderness between gilts and barrows fed diet $2(P>0.05)$. Overall, taste panelists found juiciness, tenderness, and flavor more satisfying in pork chops provided by gilts fed diet 1 and barrows fed diet 2 . These results do not agree with Stoller et al. (2003), who recorded that taste panel observations of loin chop tenderness, juiciness, and flavor intensity were not different between hogs supplemented with Paylean ${ }^{\circledR}$ and hogs fed a control diet.

\section{Correlations}

Real-time ultrasound has become very popular within the livestock industry in recent years. The ability to predict fat and muscle composition prior to slaughter assists producers in determining overall value of their animal individually. Past studies have confirmed moderate to high correlations between actual and ultrasound measurements of $10^{\text {th }}$ rib fat depth and LEA (Smith, et al., 1992; McLaren et al., 1989). In the present study, correlations between actual and ultrasound measurements of $10^{\text {th }}$ rib fat depth and LEA are located in Table 11 . Actual $10^{\text {th }}$ rib fat depth and ultra- $10^{\text {th }}$ rib were moderately correlated $(r=0.43)$. In relation, past research revealed pre-slaughter and carcass measurements to be moderately to highly correlated with values of 0.55 and 0.62 between ultrasonic backfat and $10^{\text {th }}$ rib back fat, respectively (McLaren, et al., 1989). In the 
current study, actual LEA and ultra-LEA were moderately correlated $(\mathrm{r}=0.51)$. Smith et al. (1992) reported a similar value $(r=0.53)$ for correlations between ultrasound and actual LEA, but found a higher relationship $(\mathrm{r}=0.63)$ between ultrasound and actual $10^{\text {th }}$ rib fat depth. Actual $10^{\text {th }}$ rib fat depth and actual LEA, as well as ultra- $10^{\text {th }}$ rib fat depth and ultra- LEA were negatively correlated. Although correlations in this study are numerically slightly smaller compared to past research, $r$ values are consistently fall within the moderate category (McLaren et al., 1989; Smith et al., 1992; Lo et al., 1992).

\section{IMPLICATIONS}

Data suggest that the diet containing wheat midds increased live weight, $\mathrm{HCW}$, LEA, and FFL, but the soybean diet supplemented with Paylean ${ }^{\circledR}$ produced hogs with higher ADG, and decrease in fat depth. Gender had a significant effect on overall performance, as barrows were faster growing and produced heavier live weights and HCWs, but were fatter opposite the FR, LLR, LLV and had more $10^{\text {th }}$ rib fat depth. In contrast, gilts produced leaner more muscular carcasses that had higher FFL, \% FFL, and lower U. S. Grades. Sensory attributes of juiciness, tenderness, and flavor were found more desirable in pork chops provided by gilts fed the diet containing wheat midds and the barrows fed the soybean diet supplemented with Paylean®. Real-time ultrasound aided in determining carcass value prior to slaughter, as results indicated that actual and ultrasonic measurements of $10^{\text {th }}$ rib fat depth and LEA are moderately correlated. Therefore, carcass merit and production were maximized by both diet and gender, and quality attributes of flavor and tenderness that are highly expected among consumers were not affected. 
Table 1. Diet composition of the two diets utilized in study with one including $14 \%$ wheat midds and the other combining $12 \%$ soybean meal and $9 \mathrm{~g}$ per ton of Paylean ${ }^{\circledR}$

\begin{tabular}{lrc}
\hline \hline & \multicolumn{2}{c}{ Feed Type } \\
\cline { 2 - 3 } Ingredient \% & Diet 1 & Diet 2 \\
\hline Corn & 61.44 & 65.07 \\
Soybean Meal & 2.26 & 12.67 \\
Wheat Midds & 14.37 & 0.00 \\
Corn DDGS & 20.00 & 20.00 \\
L-lysine HCl & 0.32 & 0.32 \\
L-threonine & 0.03 & 0.06 \\
Dicalcium Phosphate $18.5 \%$ & 0.00 & 0.37 \\
Limestone & 0.00 & 1.00 \\
Salt & 0.25 & 0.25 \\
Trace Mineral Premix & 0.05 & 0.08 \\
Vitamin Premix & 0.02 & 0.05 \\
Selplex 600 & 0.03 & 0.015 \\
Paylean® & 0.00 & 0.05 \\
Tylan 40 & 0.05 & 0.05 \\
\hline \hline Total & $\mathbf{1 0 0 . 0 0}$ & $\mathbf{1 0 0 . 0 0}$ \\
\hline
\end{tabular}


Table 2 . Number of crossbred ${ }^{1}$ animals included in study by gender and diet.

\begin{tabular}{|c|c|c|}
\hline \multirow[b]{2}{*}{ Gender } & \multicolumn{2}{|c|}{ Feed Type } \\
\hline & Diet $1^{2}$ & Diet $2^{3}$ \\
\hline Gilts & 13 & 22 \\
\hline Barrows & 10 & 22 \\
\hline Total & 23 & 44 \\
\hline \multicolumn{3}{|c|}{$\begin{array}{l}{ }^{1} \text { Danbred } \times \text { Yorkshire } \times \text { Landrace } \\
{ }^{2} \text { Diet } 1: \text { corn } 61.44 \% \text {, soybean meal } 2.26 \% \text {, wheat midds } 14.37 \% \text {, distillers dried grains } 20.00 \% \text {, } \\
\text { 1-lysine } \mathrm{HCl} 0.32 \% \text {, l-threonine } 0.03 \% \text {, dicalcium phosphate } 0.00 \% \text {, limestone } 0.00 \% \text {, salt } 0.25 \% \text {, } \\
\text { trace mineral premix } 0.05 \% \text {, vitamin premix } 0.02 \% \text {, Selplex } 6000.03 \% \text {, Paylean }{ }^{\circledR} 0.00 \% \text {, Tylan } \\
400.05 \% \\
{ }^{3} \text { Diet } 2: \text { corn } 65.07 \% \text {, soybean meal } 12.67 \% \text {, wheat midds } 0.00 \% \text {, distillers dried grains } 20.00 \% \text {, } \\
\text { 1-lysine } \mathrm{HCl} 0.32 \% \text {, l-threonine } 0.06 \% \text {, dicalcium phosphate } 0.37 \% \text {, limestone } 1.00 \% \text {, salt } 0.25 \% \text {, } \\
\text { trace mineral premix } 0.08 \% \text {, vitamin premix } 0.05 \% \text {, Selplex } 6000.015 \% \text {, Paylean }{ }^{\circledR} 0.05 \% \text {, } \\
\text { Tylan } 400.05 \%\end{array}$} \\
\hline
\end{tabular}


Table 3. Least squares mean for days of age, live weight, and $\mathrm{ADG}^{3}$ of crossbred gilts and barrows fed either diet $1^{1}$ or diet $2^{2}$.

\begin{tabular}{lcccccccc}
\hline \hline & \multicolumn{3}{c}{ Feed Type } & \multicolumn{2}{c}{ Gender } & \multicolumn{2}{c}{ P $>$ F } \\
\cline { 2 - 8 } Trait & $\begin{array}{c}\text { Diet 1 } \\
(\mathrm{n}=23)\end{array}$ & $\begin{array}{c}\text { Diet 2 } \\
(\mathrm{n}=44)\end{array}$ & S.E.M. ${ }^{4}$ & $\begin{array}{c}\text { Gilts } \\
(\mathrm{n}=35)\end{array}$ & $\begin{array}{c}\text { Barrows } \\
(\mathrm{n}=32)\end{array}$ & S.E.M & Feed & Sex \\
\hline Live Wt., kg & 122.45 & 120.64 & 1.40 & 120.79 & 122.30 & 1.40 & 0.3693 & 0.4304 \\
ADG (kg) & 0.68 & 0.69 & 0.01 & $0.67^{\mathrm{b}}$ & $0.71^{\mathrm{a}}$ & 0.01 & 0.2894 & 0.0076 \\
Days of Age & 181.67 & 175.30 & 3.25 & $183.02^{\mathrm{a}}$ & $173.95^{\mathrm{b}}$ & 3.21 & 0.1763 & 0.0447 \\
\hline
\end{tabular}

${ }_{\mathrm{a}, \mathrm{b}}$ Least square means in the same row (within trait) without a common superscript differ $(\mathrm{P}<0.05)$.

${ }^{1}$ Diet 1 : corn $61.44 \%$, soybean meal $2.26 \%$, wheat midds $14.37 \%$, distillers dried grains $20.00 \%$, l-lysine $\mathrm{HCl} 0.32 \%$, 1 -threonine $0.03 \%$, dicalcium phosphate $0.00 \%$, limestone $0.00 \%$, salt $0.25 \%$, trace mineral premix $0.05 \%$, vitamin premix $0.02 \%$, Selplex $6000.03 \%$, Paylean ${ }^{\circledR} 0.00 \%$, Tylan 40 $0.05 \%$

${ }^{2}$ Diet 2: corn $65.07 \%$, soybean meal $12.67 \%$, wheat midds $0.00 \%$, distillers dried grains $20.00 \%$, 1-lysine $\mathrm{HCl} 0.32 \%$, 1-threonine $0.06 \%$, dicalcium phosphate $0.37 \%$, limestone $1.00 \%$, salt $0.25 \%$, trace mineral premix $0.08 \%$, vitamin premix $0.05 \%$, Selplex $6000.015 \%$, Paylean ${ }^{\circledR} 0.05 \%$, Tylan $400.05 \%$

${ }^{3}$ Average Daily Gain (live weight/days of age)

${ }^{4}$ S.E.M.: Standard Error of the Mean 
Table 4. Least squares mean for carcass traits of crossbred gilts and barrows fed either diet $1^{1}$ or diet $2^{2}$.

\begin{tabular}{|c|c|c|c|c|c|c|c|c|}
\hline \multirow[b]{2}{*}{ Trait } & \multicolumn{3}{|c|}{ Feed Type } & \multicolumn{3}{|c|}{ Gender } & \multicolumn{2}{|c|}{$\mathbf{P}>\mathbf{F}$} \\
\hline & $\begin{array}{c}\text { Diet 1 } \\
(\mathrm{n}=23)\end{array}$ & $\begin{array}{c}\text { Diet } 2 \\
(\mathrm{n}=44)\end{array}$ & S.E.M. ${ }^{11}$ & $\begin{array}{c}\text { Gilts } \\
(\mathrm{n}=35)\end{array}$ & $\begin{array}{l}\text { Barrows } \\
(\mathrm{n}=32)\end{array}$ & S.E.M. & Feed & Sex \\
\hline $\mathrm{HCW}, \mathrm{kg}^{3}$ & 93.14 & 91.31 & 1.16 & 91.27 & 93.19 & 1.15 & 0.2764 & 0.2294 \\
\hline $\mathrm{MS}^{4}$ & 2.13 & 2.05 & 0.05 & 2.07 & 2.11 & 0.05 & 0.2036 & 0.5221 \\
\hline $\mathrm{FR}, \mathrm{cm}^{5}$ & 4.01 & 3.99 & 0.12 & $3.78^{b}$ & $4.22^{\mathrm{a}}$ & 0.12 & 0.8912 & 0.0092 \\
\hline $\mathrm{LR}, \mathrm{cm}^{6}$ & 2.23 & 2.20 & 0.08 & $2.05^{b}$ & $2.38^{\mathrm{a}}$ & 0.08 & 0.8234 & 0.0029 \\
\hline $\mathrm{LLV}, \mathrm{cm}^{7}$ & 1.66 & 1.82 & 0.09 & $1.54^{\mathrm{b}}$ & $1.94^{\mathrm{a}}$ & 0.09 & 0.2120 & 0.0016 \\
\hline 10th rib fat, $\mathrm{cm}$ & 1.70 & 1.67 & 0.10 & $1.51^{\mathrm{b}}$ & $1.85^{\mathrm{a}}$ & 0.10 & 0.8099 & 0.0138 \\
\hline LEA, $\mathrm{cm}^{8}$ & 53.04 & 51.44 & 1.93 & 54.22 & 50.26 & 1.90 & 0.5643 & 0.1369 \\
\hline FFL, $\mathrm{kg}^{9}$ & 51.88 & 50.60 & 0.86 & 51.77 & 50.71 & 0.87 & 0.3987 & 0.2806 \\
\hline$\% \mathrm{FFL}^{10}$ & 55.64 & 55.51 & 0.24 & $56.88^{\mathrm{a}}$ & $54.27^{b}$ & 0.60 & 0.8880 & 0.0027 \\
\hline Dressing \% & 76.06 & 75.68 & 0.31 & 75.56 & 76.17 & 0.30 & 0.3932 & 0.1509 \\
\hline U.S. Grade & 1.38 & 1.42 & 0.14 & $1.15^{\mathrm{b}}$ & $1.64^{\mathrm{a}}$ & 0.14 & 0.8171 & 0.0137 \\
\hline 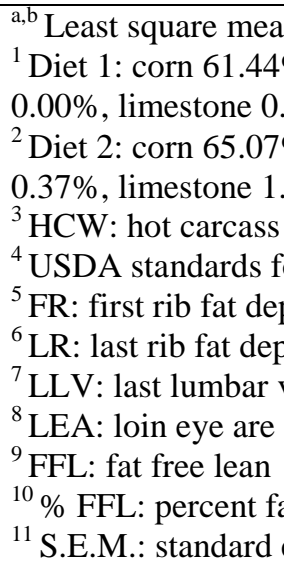 & $\begin{array}{l}\text { row (within } \\
\text { eal } 2.26 \% \text {, wh } \\
\% \text {, trace min } \\
\text { eal } 12.67 \% \text {, v } \\
\% \text {, trace min } \\
\text { re as a result c } \\
\text { pth }\end{array}$ & $\begin{array}{l}\text { ait) without } \\
\text { at midds } 14 \text {. } \\
\text { al premix } 0 . \\
\text { eat midds } 0 . \\
\text { al premix } 0 . \\
\text { evaluated th }\end{array}$ & $\begin{array}{l}\text { mmon supers } \\
\text {, distillers dr } \\
\text {, vitamin pre } \\
\text {, distillers dr } \\
\text {, vitamin pre } \\
\text { hess (1-thin, } 2\end{array}$ & $\begin{array}{l}\text { t differ }(\mathrm{P}<0 \\
\text { grains } 20.00 \% \\
0.02 \%, \text { Selpl } \\
\text { grains } 20.00 \% \\
0.05 \%, \text { Selpl } \\
\text { erage and 3-t }\end{array}$ & $\begin{array}{l}\text { ). } \\
\text {-lysine } \mathrm{HCl} 0 . \\
6000.03 \%, \mathrm{~Pa} \\
\text {-lysine } \mathrm{HCl} 0 . \\
6000.015 \%, \mathrm{~F} \\
)^{2}\end{array}$ & $\begin{array}{l}\text { 1-threonin } \\
\text { (®) } 0.00 \% \text {, } \\
\text { 1-threonin } \\
\text { n® } 0.05 \%\end{array}$ & $\begin{array}{l}\% \text {, dicalci } \\
400.05 \% \\
\% \text {, dicalcil } \\
\text { in } 400.05 \%\end{array}$ & $\begin{array}{l}\text { hosphate } \\
\text { nosphate }\end{array}$ \\
\hline
\end{tabular}


Table 5. Least squares mean for $\mathrm{pH}$ and temperature values of the semimembranosus muscle of the ham and the longissimus dorsi muscle of the loin of crossbred gilts and barrows fed either diet $1^{1}$ or diet $2^{2}$.

\begin{tabular}{|c|c|c|c|c|c|c|c|c|}
\hline \multirow[b]{2}{*}{ Trait } & \multicolumn{3}{|c|}{ Feed Type } & \multicolumn{3}{|c|}{ Gender } & \multicolumn{2}{|c|}{$\mathbf{P}>\mathbf{F}$} \\
\hline & $\begin{array}{c}\text { Diet 1 } \\
(\mathrm{n}=23)\end{array}$ & $\begin{array}{c}\text { Diet } 2 \\
(\mathrm{n}=44)\end{array}$ & S.E.M. ${ }^{3}$ & $\begin{array}{c}\text { Gilts } \\
(\mathrm{n}=35)\end{array}$ & $\begin{array}{l}\text { Barrows } \\
(\mathrm{n}=32)\end{array}$ & S.E.M. & Feed & Sex \\
\hline \multicolumn{9}{|l|}{ Ham } \\
\hline $1 \mathrm{hr} \mathrm{PH}$ & 6.52 & 6.60 & 0.05 & 6.57 & 6.55 & 0.05 & 0.2986 & 0.6858 \\
\hline $3 \mathrm{hr} \mathrm{PH}$ & 5.89 & 5.92 & 0.05 & 5.90 & 5.91 & 0.09 & 0.6598 & 0.8182 \\
\hline $24 \mathrm{hr} \mathrm{PH}$ & 5.72 & 5.72 & 0.04 & 5.69 & 5.76 & 0.04 & 0.9865 & 0.2193 \\
\hline $1 \mathrm{hr}$ Temp & 40.96 & 40.93 & 0.09 & 41.00 & 40.89 & 0.09 & 0.8260 & 0.3550 \\
\hline $3 \mathrm{hr}$ Temp & $32.03^{\mathrm{a}}$ & $29.51^{b}$ & 0.61 & 30.46 & 31.09 & 0.60 & 0.0052 & 0.4517 \\
\hline $24 \mathrm{hr}$ Temp & 2.42 & 2.34 & 0.12 & 2.25 & 2.52 & 0.12 & 0.6554 & 0.1058 \\
\hline \multicolumn{9}{|l|}{ Loin } \\
\hline $1 \mathrm{hr} \mathrm{PH}$ & 6.32 & 6.43 & 0.05 & 6.41 & 6.34 & 0.05 & 0.1257 & 0.2466 \\
\hline $3 \mathrm{hr} \mathrm{PH}$ & 5.83 & 5.79 & 0.04 & 5.81 & 5.81 & 0.07 & 0.4642 & 0.9058 \\
\hline $24 \mathrm{hr} \mathrm{PH}$ & 5.66 & 5.65 & 0.03 & 5.64 & 5.67 & 0.03 & 0.9116 & 0.5142 \\
\hline $1 \mathrm{hr}$ Temp & $40.16^{\mathrm{a}}$ & $39.15^{\mathrm{b}}$ & 0.16 & 39.51 & 39.80 & 0.16 & 0.0001 & 0.2052 \\
\hline 3 hr Temp & $19.59^{\mathrm{a}}$ & $16.12^{\mathrm{b}}$ & 0.70 & $16.84^{\mathrm{b}}$ & $18.87^{\mathrm{a}}$ & 0.69 & 0.0009 & 0.0375 \\
\hline $24 \mathrm{hr}$ Temp & 1.26 & 1.17 & 0.06 & $1.12^{\mathrm{b}}$ & $1.31^{\mathrm{a}}$ & 0.06 & 0.2468 & 0.0175 \\
\hline
\end{tabular}

${ }^{\mathrm{a}, \mathrm{b}}$ Least square means in the same row (within trait) without a common superscript differ $(\mathrm{P}<0.05)$.

${ }^{1}$ Diet 1: corn $61.44 \%$, soybean meal $2.26 \%$, wheat midds $14.37 \%$, distillers dried grains $20.00 \%$, 1-lysine $\mathrm{HCl} 0.32 \%$, 1 -threonine $0.03 \%$, dicalcium phosphate $0.00 \%$, limestone $0.00 \%$, salt $0.25 \%$, trace mineral premix $0.05 \%$, vitamin premix $0.02 \%$, Selplex $6000.03 \%$, Paylean ${ }^{\circledR}$ $0.00 \%$, Tylan $400.05 \%$

${ }^{2}$ Diet 2: corn $65.07 \%$, soybean meal $12.67 \%$, wheat midds $0.00 \%$, distillers dried grains $20.00 \%$, 1-lysine $\mathrm{HCl} 0.32 \%$, 1-threonine $0.06 \%$, dicalcium phosphate $0.37 \%$, limestone $1.00 \%$, salt $0.25 \%$, trace mineral premix $0.08 \%$, vitamin premix $0.05 \%$, Selplex $6000.015 \%$, Paylean ${ }^{\circledR}$ $0.05 \%$, Tylan $400.05 \%$

${ }^{3}$ S.E.M.: Standard Error of the Mean 
Table 6. Least squares mean for subjective assessments of pork quality attributes of muscle color, texture, and firmness by evaluation of the cut surface of the loin chops provided by crossbred gilts and barrows fed either diet $1^{1}$ or diet $2^{2}$.

\begin{tabular}{|c|c|c|c|c|c|c|c|c|}
\hline \multirow[b]{2}{*}{ Trait } & \multicolumn{3}{|c|}{ Feed Type } & \multicolumn{3}{|c|}{ Gender } & \multicolumn{2}{|c|}{$\mathbf{P}>\mathbf{F}$} \\
\hline & $\begin{array}{c}\text { Diet 1 } \\
(\mathrm{n}=23)\end{array}$ & $\begin{array}{c}\text { Diet } 2 \\
(\mathrm{n}=44)\end{array}$ & S.E.M. ${ }^{7}$ & $\begin{array}{c}\text { Gilts } \\
(\mathrm{n}=35)\end{array}$ & $\begin{array}{l}\text { Barrows } \\
(\mathrm{n}=32)\end{array}$ & S.E.M. & Feed & Sex \\
\hline Muscle Color ${ }^{3}$ & 2.42 & 2.36 & 0.29 & 2.42 & 2.36 & 0.14 & 0.7995 & 0.7611 \\
\hline Texture $^{4}$ & 5.08 & 5.38 & 0.33 & 5.19 & 5.28 & 0.32 & 0.5312 & 0.8483 \\
\hline Firmness ${ }^{5}$ & 2.00 & 2.20 & 0.18 & 2.21 & 1.20 & 0.17 & 0.4315 & 0.3754 \\
\hline Cook loss $\%^{6}$ & 22.96 & 21.03 & 1.93 & 23.89 & 20.10 & 1.91 & 0.4866 & 0.1537 \\
\hline $\begin{array}{l}{ }^{1} \text { Diet } 1 \text { : corn } 61 . \\
\text { dicalcium phosph } \\
0.00 \% \text {, Tylan } 40 \\
0.2 \text { Diet 2: corn } 65 . \\
\text { dicalcium phosph } \\
\text { dium, Tylan } 40 \\
0.05 \% \\
{ }^{3} \text { National Pork P } \\
{ }^{4} \text { An eight point s } \\
{ }^{5} \text { A three point sca } \\
=\text { very firm-cut } \\
{ }^{6} \text { Cook loss \%: pe } \\
{ }^{7} \text { S.E.M.: Standar }\end{array}$ & $\begin{array}{l}\text { an meal } 2.26 \\
\text { limestone } 0 . \\
\text { an meal } 12.6 \\
\text { limestone } 1 . \\
\text { ouncil (NPPC } \\
\text { ed for textur } \\
\text { d for firmnes } \\
\text { to be smoo } \\
\text { ence calcula } \\
\text { he Mean }\end{array}$ & $\begin{array}{l}\text { wheat midd } \\
\% \text {, salt } 0.25 \% \\
\% \text {, wheat mid } 0.25 \% \\
\text { color using th } \\
=\text { extremely } \\
=\text { soft-cut } \mathrm{s} \\
\text { between rau }\end{array}$ & $\begin{array}{l}37 \% \text {, distil } \\
\text { ce mineral } \\
00 \% \text {, distil } \\
\text { ce mineral } \\
99 \text { standar } \\
\text { rse, } 8=\text { ex } \\
\text { ces distort } \\
\text { ght and co }\end{array}$ & $\begin{array}{l}\text { dried grain } \\
\text { emix } 0.05 \% \text {, } \\
\text { dried grain } \\
\text { emix } 0.08 \% \text {, } \\
\text { nely fined te } \\
\text { ily and are v } \\
\text { ed weight }\end{array}$ & $\begin{array}{l}00 \% \text {, l-lysir } \\
\text { min premix } \\
00 \% \text {, 1-lysir } \\
\text { min premix } \\
\text { d). } \\
\text { soft, } 2=\text { f }\end{array}$ & $\begin{array}{l}10.32 \% \text {, } \\
\%, \text { Selple } \\
\text { \%, Selple } \\
0.32 \% \text {, } \\
\text { ut surface }\end{array}$ & $\begin{array}{l}\text { eonine } 0 . \text {. } \\
0.03 \%, 1 \\
\text { eonine } 0 .( \\
0.015 \% \text {, } \\
\text { d to hold }\end{array}$ & shape, 3 \\
\hline
\end{tabular}


Table 7. Least squares mean for subjective assessments of pork quality attributes of juiciness, tenderness, and pork flavor of loin chops provided by crossbred gilts and barrows fed either diet $1^{1}$ or diet $2^{2}$.

\begin{tabular}{|c|c|c|c|c|c|}
\hline \multirow[b]{2}{*}{ Trait } & \multicolumn{5}{|c|}{ Gender/Diet Interaction } \\
\hline & $\begin{array}{c}\text { Gilts } \\
\text { (Diet 1; } \\
\mathrm{n}=13 \text { ) }\end{array}$ & $\begin{array}{c}\text { Gilts } \\
\text { (Diet 2; } \\
\mathrm{n}=22 \text { ) }\end{array}$ & $\begin{array}{c}\text { Barrows } \\
\text { (Diet 1; } \\
\mathrm{n}=10 \text { ) }\end{array}$ & $\begin{array}{c}\text { Barrows } \\
\text { (Diet 2; } \\
\mathrm{n}=22 \text { ) }\end{array}$ & $\mathrm{P}>\mathrm{F}$ Interaction \\
\hline \multicolumn{6}{|l|}{ Juiciness $^{3}$} \\
\hline Initial & 6.15 & 5.67 & 5.39 & 5.93 & 0.0022 \\
\hline S.E.M. & 0.29 & 0.28 & 0.31 & 0.27 & \\
\hline Sustained & 5.73 & 5.37 & 4.99 & 5.67 & 0.0016 \\
\hline S.E.M. & 0.27 & 0.25 & 0.29 & 0.25 & \\
\hline \multicolumn{6}{|l|}{ Tenderness ${ }^{4}$} \\
\hline Initial & 6.29 & 5.43 & 5.15 & 5.79 & 0.0001 \\
\hline S.E.M. & 0.30 & 0.28 & 0.31 & 0.27 & \\
\hline Sustained & 6.00 & 5.24 & 4.90 & 5.65 & 0.0001 \\
\hline S.E.M & 0.28 & 0.26 & 0.29 & 0.25 & \\
\hline Pork Flavor ${ }^{5}$ & 5.56 & 5.39 & 4.91 & 5.68 & 0.0027 \\
\hline S.E.M. ${ }^{6}$ & 0.29 & 0.27 & 0.30 & 0.26 & \\
\hline
\end{tabular}

${ }^{\mathrm{a}, \mathrm{b}}$ Least square means in the same row (within trait) without a common superscript differ $(\mathrm{P}<0.05)$.

${ }^{1}$ Diet 1 : corn $61.44 \%$, soybean meal $2.26 \%$, wheat midds $14.37 \%$, distillers dried grains $20.00 \%$, $1-1 y$ sine $\mathrm{HCl} 0.32 \%$, 1 -threonine $0.03 \%$, dicalcium phosphate

$0.00 \%$, limestone $0.00 \%$, salt $0.25 \%$, trace mineral premix $0.05 \%$, vitamin premix $0.02 \%$, Selplex $6000.03 \%$, Paylean ${ }^{\circledR} 0.00 \%$, Tylan $400.05 \%$

${ }^{2}$ Diet 1 : corn $61.44 \%$, soybean meal $2.26 \%$, wheat midds $14.37 \%$, distillers dried grains $20.00 \%$, 1-lysine $\mathrm{HCl} 0.32 \%$, 1 -threonine $0.03 \%$, dicalcium phosphate

$0.00 \%$, limestone $0.00 \%$, salt $0.25 \%$, trace mineral premix $0.05 \%$, vitamin premix $0.02 \%$, Selplex $6000.03 \%$, Payleanß $0.00 \%$, Tylan $400.05 \%$

${ }^{3}$ Initial and sustained juiciness $(8=$ extremely juicy, $1=$ extremely dry).

${ }^{4}$ Initial and sustained tenderness $(8=$ extremely tender, $1=$ extremely tough).

${ }^{5}$ Pork flavor ( $8=$ extremely intense, $1=$ extremely bland $)$.

${ }^{6}$ S.E.M.: Standard Error of the Mean 
Table 8. Correlations between actual and ultrasound measurements of $10^{\text {th }}$ rib fat depth ${ }^{1}$ and LEA $^{2}$ for commercial crossbred and purebred Yorkshire gilts and barrows $(n=88)^{3}$.

\begin{tabular}{|c|c|c|c|c|}
\hline \multirow[b]{2}{*}{ Trait } & \multicolumn{4}{|c|}{ Measurement } \\
\hline & $\begin{array}{c}10^{\text {th }} \\
\text { rib fat depth }\end{array}$ & LEA & $\begin{array}{c}\text { Ultra } 10^{\text {th }} \\
\text { rib fat depth }\end{array}$ & Ultra LEA \\
\hline $10^{\text {th }}$ rib fat depth & & -0.47 & $0.43 * *$ & -0.14 \\
\hline $\begin{array}{l}\text { LEA } \\
\text { Ultra } 10^{\text {th }} \text { rib fat } \\
\text { depth }^{4}\end{array}$ & & & $-0.42 * *$ & $0.51 * *$ \\
\hline $\begin{array}{l}{ }^{1} 10^{\text {th }} \text { rib fat depth: } \\
\text { opposite the cut sur } \\
{ }^{2} \text { LEA: loin eye area } \\
{ }^{3} \text { Number of comme } \\
\text { ultrasound measure } \\
{ }^{4} \text { Ultra } 10^{\text {th }} \text { rib fat de } \\
{ }^{5} \text { Ultra LEA: Measu } \\
{ }^{* *} \text { Correlation is sig }\end{array}$ & $\begin{array}{l}\text { back fat. Measu } \\
\text { the loin eye. } \\
\text { urement of area } \\
\text { ossbred and pur } \\
\text { leasurement of } 1 \\
\text { of loin eye area } \\
\text { t when } \mathrm{P}<0.01\end{array}$ & $\begin{array}{l}\text { nent of } \\
\text { the cut } \\
\text { red York } \\
\text { rib back } \\
\text { the ultr }\end{array}$ & $\begin{array}{l}\text { located at the } \\
\text { e of the loin ey } \\
\text { gilts and barrov } \\
\text { nultrasonograp } \\
\text { graphy screen. }\end{array}$ & $\begin{array}{l}\text { three quarter } \\
\text { d in } \\
\text { n. }\end{array}$ \\
\hline
\end{tabular}




\section{REFERENCES}

Apple, J. K., C. V. Maxwell, B. R. Kutz, L. K. Rakes, J. T. Sawyer, Z. B. Johnson, T. A. Armstrong, S. N. Carr, and P. D. Matzar. 2007. Interactive effect of ractopamine and dietary fat source on pork quality characteristics of fresh pork chops during simulated retail display. J. Anim. Sci. 86:2711-2722.

Armstrong, T. A., D. J. Ivers, J. R. Wagner, D. B. Anderson, W. C. Weldon, and E. P. Berg. 2004. The effect of dietary ractopamine concentration and duration of feeding on growth performance, carcass characteristics, and meat quality of finishing pigs. J. Anim. Sci.82:3245-3253.

Bereskin, B., and R. J. Davey. 1978. Genetic, sex, and diet effects on pig carcass traits. J. Anim. Sci. 46:1581-1591

Bohrer, B.M., J.M. Kyle, D.D. Boler, P.J. Rincker, M.J. Ritter, and S.N. Carr. 2012. Meta-analysis of the effects of ractopamine hydrochloride on carcass cutabilility and primal yields of finishing pigs. J. Anim. Sci. 91:1015-1023.

Boland, M.A., K.A. Foster, A.P. Schinekel, J. Wagner, W. Chen, E.P. Berg, and J.C. Forrest.1995. Alternative pork carcass evaluation techniques: I. Differences in predictions of value. J. Anim. Sci. 73:637-644.

Bowker, B.C., A.L. Grant, J.C. Forrest, and D.E. Gerrard. 2000. Muscle metabolism and PSE pork. J. Anim. Sci. 79:1-8.

Brana, D. V., G. A. Rojo-Gomez, M. Ellis, and J. A. Cuaron. 2013. Effect of gender (gilt 
and surgically and immunocastrated male) and ractopamine hydrochloride supplementation on growth performance, carcass, and pork quality characteristics of finishing pigs under commercial conditins. J. Anim. Sci. 91:5894-6545.

Carr, S. N., D. J. Ivers, D. B. Anderson, D. J. Jones, D. H. Mowery, M. B. England, J. Killefer, P.J. Rincker, and F. K. McKeith. 2005. The effects of ractopamine hydrochloride on lean carcass yields and pork quality characteristics. J. Anim. Sci. 83:2886-2893.

Christian, L. L., K. L. Strock, and J. P. Carlson. 1980. Effects of protein, breed cross, sex and slaughter weight on swine performance and carcass traits. J. Anim. Sci. 51:51-58.

Cisneros, F., M. Ellis, F. K. McKeith, J. McCaw, and R. Fernando. 1996. Influence of slaughter weight on growth carcass characteristics, commercial cutting and curing yields, and meat quality of barrows and gilts from two genotypes. J. Anim. Sci. 74:925-933.

Distillers Grains Technology Council. 2005. Available: http://www.distillersgrains.org/grains/availability.html Accessed: April 9, 2013

Elanco. 2012. Products and Services. Swine. Available: https://www.elanco.us/products-services/swine/ Accessed: April 9, 2013

Ellis, M., A. J. Webb, P. J. Avery, and I. Brown. 1996. The influence of terminal sire 
genotype, sex, slaughter weight, feeding regime and slaughter-house on growth performance and carcass and meat quality in pigs and on the organoleptic properties of fresh pork. J. Anim. Sci. 62:521-530.

Eutech Instruments. 1997. Measuring the $\mathrm{pH}$ value of meat. Available: http://www.eutechinst.com/techtips/tech-tips35.htm Accessed: April 1, 2013.

Freise, K., S. Brewer and J. Novakofski. 2005. Duplication of the pale, soft, and exudative condition starting with normal postmortem pork. J. Anim. Sci. 83:28432852.

Gerlemann, G. D., G. L. Allee, P. J. Rincker, M. J. Ritter, D. D. Boler, and S. N. Carr. 2014. Impact of ractopamine hydrochloride on growth, efficiency, and carcass traits of finishing pigs in a three-phase marketing strategy. J. Anim. Sci. 92:12001207.

Global Swine Exchange of Iowa. Crossbreeding Systems. Available: http://www.globalswine.com/crossbreedingsystems.html Accessed: April 1, 2013

Hamilton, D. N., M. Ellis, B. F. Wolter, A. P. Schinckel, and E. R. Wilson. 2003. The growth performance of the progeny of two swine sire lines reared under different floor space allowances. J. Anim. Sci. 81:1126-1135.

Hinson, R.B., H.O. Galloway, D.D. Boler, M.J. Ritter, F.K. McKeith, and S.N. Carr. 2012Effects of feeding ractopamine (Paylean) on growth and carcass traits in $\mathrm{f}$ inishing pigs marketed at equal slaughter weights. J. Anim. Sci. 28:657-663.

Hyun, Y., G. E. Bressner, R. L. Fischer, P. S. Miller, M. Ellis, B. A. Peterson, E. P. 
Stanisiewski, and G. F. Hartnell. 2005. Performance of growing-finishing pigs fed diets containing YieldGard Rootworm corn (MON 863), a nontransgenic genetically similar corn, or conventional corn hybrids. J. Anim. Sci. 83:15811590.

Kauffman, R.G., D. Wachholz, D. Henderson, and J.V. Lochner. 1978. Shrinkage of PSE, normal and DFD hams during transit and processing. J. Anim. Sci. 46:12361240.

Kosovac, O., B. Zivkocvic, C. Radovic, and T. Smiljakovic. 2009. Quality indicators: carcass side and meat quality of pigs of different genotypes. Bio. Anim. Husb. 25:173-188.

Kuhlers, D., N.K. Nadarajah, S. Jungst, E. Huff-Longergan, S.M. Lonergan, and B.L. Anderson.1998. Sonic swine ultrasound equipment helping produce leaner pork. Highlights of Agricultrual Research. 45:4.

Latorre, M.A., R. Lazaro, D. G. Valencia, P. Medel, and G. G. Mateos. 2004. The effects of gender and slaughter weight on the growth performance, carcass traits, and meat quality characteristics of heavy pigs. J. Anim. Sic. 82:526-533.

Leick, C. M., C. L. Puls, M. Ellis, J. Killefer, T. R. Carr, S. M. Scramlin, M. B. England, A. M. Gaines, B. F. Wolter, S. N. Carr, and F. K. McKeith. 2010. Effect of distillers dried grans with solubles and ractopamine (Paylean) on quality and shelf-life of fresh pork and bacon. J. Anim. Sci. 88:2751-2766.

Lo, L. L., D. G. McLaren, F. K. McKeith, R. L. Fernando, and J. Novakofski. 1992. 
Genetic analyses of growth, real-time ultrasound, carcass, and pork quality traits in Duroc and Landrace pigs: II. Heritabilities and correlations. J. Anim. Sci. 70:2387-2396.

McLaren, D. G., F. M. McKeith and J. Novakofski. 1989. Prediction of carcass characteristics of market weight from serial real-time ultrasound measures of backfat and loin eye area in the growing pig. J. Anim. Sci. 67:1657-1667.

NPPC. 1991. Procedures to Evaluate Market Hogs. 3rd ed. National Pork Producers Council, Des Moines, IA.

NRC. 1998. Nutrient Requirements of Swine. $10^{\text {th }}$ rev. ed. Natl. Acad. Press. Washington, D.C.

Pedersen, C., M. G. Boersma, and H. H. Stein. 2007. Digestibility of wheat shorts in swine diets. J. Anim. Sci. 45:1294-1301.

Plain, R., and G. Grimes. 2001. Marketing slaughter hogs under contract. Pork Check Off. Fact Sheet. Pork Information Gateway. Available: http://www.pork.org/filelibrary/Factsheets/PIGFactsheets/NEWfactSheets/11-0301g.pdf Accessed: April, 2013

Plimpton, R.F., and H.S. Teague. 1972. Influence of sex and hormone treatment on performance and carcass composition of swine. J. Anim. Sci. 35:116-1175.

Pork Check Off. 2008. Alternative feed ingredients in swine diets II: Use, advantages, and disadvantages of common alternative feedstuffs. Available: http://www.pork.org/filelibrary/AnimalScience/Alt_Feed_2.pdf Accessed: April, 2014 
Pork Check Off. 2012. Quick Facts, Pork Industry at a Glance. Available:

http://viewer.zmags.com/publication/5bb6aa6d\#/5bb6aa6d/16

Accessed: April 1, 2013

Premier Nutrition Technologies. 2006. Research proven to increase fat-free lean growth by $34 \%$. Elanco Paylean. Available:

http://www.pntechnologies.com/ourproductspayleandetails.htm Accessed: April 1, 2013.

Ross, K.A., A.D. Beaulieu, J. Merrill, G. Vessie, and J.F. Patience. 2011. The impact of ractopamine hydrochloride on growth and metabolism, with special consideration of its role on nitrogen balance and water utilization in pork production. J. Anim. Sci. 89:2243-2256.

Salyer, J.A., J. M. DeRouchey, M. D. Tokach, S. S. Dritz, R. D. Goodband, J. L. Nelssen, and D. B. Petry. 2012. Effects of dietary wheat middling, distillers dried grainswith soulubles, and choice grease on growth performance, carcass characteristics, and carcass fat quality of finishing pigs. J. Anim. Sci. 90:26202630.

Schinckel, A. P., N. Li, B. T. Richert, P. V. Preckel, and M. E. Einstein. 2003. Development of a model to describe the compositional growth and dietary lysine requirements of pigs fed ractopamine. J. Anim. Sci. 81:1106-1119.

Schneider, J.F., L.L. Christian, and D.L. Kuhlers. 1982. Crossbreeding in swine: genetic effects on pig growth and carcass merit. J. Anim. Sci. 54:747-756. 
Schroeder, T. C., J. Mintert, and E. Berg. 2004. Valuing market hogs: information and pricing issues. Kansas State University Agricultural Experiment Station and Cooperative Extension Service MF-2644.

Shaw, D. T., D. W. Rozeboom, G. M. Hill, A. M. Booren, and J. E. Link. 2002. Impact of vitamin and mineral supplement withdrawl and wheat middling inclusion on the finishing pig growth performance, fecal mineral concentration, carcass characteristics, and the nutrient content and oxidative stability of pork. J. Anim. Sci. 80:2920-2930.

Smith, B. S., W. R. Jones, J. D. Hough, D. L. Huffman, W. B. Mikel, and D. R. Mulvaney. 1992. Prediction of carcass characteristics by real-time ultrasound in barrows and gilts slaughtered at three weights. J. Anim. Sci. 70:2304-2308.

Stein, H.H., and G.C. Shurson. 2008. The use and application of distillers dried grains with solubles in swine diets. J. Anim. Sci. 87:1292-1303.

Stites, C. R., F. K. McKeith, S. D. Singh, P. J. Bechtel, D. H. Mowery, and D. J. Jones. 1991.The effect of ractopamine hydrochloride on the carcass cutting yields of finishing swine. J. Anim. Sci. 69:3094-3101.

Stoller, G. M., H. N. Zerby, S. J. Moeller, T. J. Baas, C. Johnson and L. E. Watkins. 2003. The effect of feeding ractopamine (Paylean) on muscle quality and sensory characteristics in three diverse genetic lines of swine. J. Anim. Sci. 81:1508-1516.

Stouffer, J. R. 2004. History of ultrasound in animal science. J. Ultra. Med. 23:577-584.

Thaler, B. 2002. Use of distillers dried grains with solubles (DDGS) in swine diets. South Dakota State Cooperative Extension Service. Available: http://www.distillersgrains.org/files/feedsource/swine_Thaler_DDG_Diets.pdf 
Accessed: April 9, 2013

The Pig Site. 2013. Influence of paylean (ractopamine hydrochloride) on pork quality. 5M Publishing. Available:

http://www.thepigsite.com/articles/4236/influence-of-paylean-ractopamine hydrochloride-on-pork-quality Accessed: March 1, 2014.

Trefan, L., A. Doeschl-Wilson, J. A. Rooke, C. Terlouw, and L. Bunger. 2013. Meta analysis of effects of gender in combination with carcass weight and breed on pork quality. J. Anim. Sci. 91:1480-1492.

USDA. 1985. United States standards for grades of pork carcasses. Agricultural Marketing Service, USDA, Washington, DC.

USDA National Agricultural Statistics Service. 2014. Livestock Slaughter. Commercial red meat production up from last year. ISSN: 0499-0544.

USDA National Agricultural Statistics Service. 2013. Farms, land in farms and livestock operations 2012 summary. ISSN: 1930-7126.

USDA Foreign Agricultural Service. 2008. Available: http://www.fas.usda.gov/psdonline/circulars/livestock_poultry.pdf Accessed: April 9, 2013

USDA Foreign Agricultural Service. 2013. Livestock and poultry: world markets and trade. Available: http://apps.fas.usda.gov/psdonline/circulars/livestock_poultry.pdf Accessed: March 1, 2014

U.S. Environmental Protection Agency. 2013. Ag 101. Background of pork production in 
U.S. Available:

http://www.epa.gov/oecaagct/ag101/porkbackground.html Accessed: February 26, 2013 
VITA

Kassindra Jo Winn

Candidate for the Degree of

Master of Science

Thesis: $\quad$ PRODUCTION, CARCASS, AND MEAT QUALITY

CHARACTERISTICS OF COMMERCIAL CROSSBRED GILTS AND BARROWS FED TWO DIFFERENT DIETS

Major Field: Animal Science

Biographical:

Education:

Completed the requirements for the Master of Science in Meat Science at Oklahoma State University, Stillwater, Oklahoma in May 2014.

Completed the requirements for the Bachelor of Science in Animal Science at Oklahoma State University, Stillwater, Oklahoma in May 2012.

Experience:

Graduate Teaching Assistant, Oklahoma State University, Stillwater, OK

June 2012 - May 2014

Professional Memberships:

American Meat Science Association 